\section{MedïEal Seilenee}

pISSN 2321-7359; eISSN 2321-7367

To Cite:

Mhna NB, Mousa H, Alqahtani A, Nasser G, Hamdi S, Amer N,

Alsadoon M, Alzahrani KT, Almahroos H, Alghamdi B, Alsharif A, Kashkari H, Abuzinadah SH. Medical Science, 2022, 26, ms35e2050.

doi: https://doi.org/10.54905/disssi/v26i119/ms35e2050

Author Affiliation:

${ }^{1}$ lecturer and specialist, pedodontics Dentistry Department, Ibn Sina

National College, Jeddah, Saudi Arabia

${ }^{2}$ General Dentist, Ministry of Health, Saudi Arabia

${ }^{3}$ Dental Undergraduate Ibn Sina National College, Jeddah, Saudi Arabia

${ }^{4}$ Dental Undergraduate, King Abdulaziz University faculty of dentistry,

Jeddah, Saudi Arabia

${ }^{5}$ Dental intern, Ibn Sina National College, Jeddah, Saudi Arabia

${ }^{6}$ Dental intern, Riyadh Elm University, Riyadh, Saudi Arabia

${ }^{7}$ BDS, PGD in Endo, Ministry of Health, Saudi Arabia

${ }^{8}$ General Dentist, King Abdul-Aziz University Dental Hospital, Jeddah, Saudi Arabia

${ }^{9}$ Assistant Professor and Consultant of Restorative and Digital Dentistry, Restorative Dentistry Department, King Abdul-Aziz University, Faculty of Dentistry, Jeddah, Saudi Arabia

Peer-Review History

Received: 17 December 2021

Reviewed \& Revised: 19/December/2021 to 13/January/2022

Accepted: 15 January 2022

Published: 18 January 2022

Peer-review Method

External peer-review was done through double-blind method.

URL: https://www.discoveryjournals.org/medicalscience

\section{(c) (1)}

This work is licensed under a Creative Commons Attribution 4.0 International License.
Primary teeth importance and dental care of children among mothers in Saudi Arabia: Knowledge and awareness assessment

\author{
Naif bin mhna ${ }^{1}$, Haneen Mousa ${ }^{2}$, Alhanouf Alqahtani' ${ }^{2}$, \\ Ghadeer Nasser ${ }^{3}$, Suzan Hamdi', Nura Amer ${ }^{5}$, Mashaal \\ Alsadoon $^{6}$, Khames T. Alzahrani ${ }^{7}$, Hassan Almahroos ${ }^{2}$, \\ Bushra Alghamdi ${ }^{4}$, Arwa Alsharif ${ }^{2}$, Hadeel Kashkari ${ }^{8}$, \\ Samar H Abuzinadah ${ }^{9}$
}

\begin{abstract}
Background: Parent's belief and attitude about children's oral health is very crucial to enhance their children's oral health. Mothers can help their children establish dental care habits if they are well acquainted with oral prevention and diseases techniques. The purpose of this study was to measure mothers' knowledge and awareness of primary teeth and their value in the lives of their children. Methods: A-cross-sectional study was carried out through selfadministered questionnaire which distributed to around 841 mothers in different regions in Saudi Arabia. Information regarding, mother education, children's oral habits and dental preventive measures was obtained. Data was entered using the Office Excel program (2016) for windows. The data was then transferred to the Statistical Package of Social Science Software (SPSS) version 20 program. Result: A total of 841 participants who responded for the questionnaire. The mean age of the study participants was $34.29 \pm 9.43$ years. 40.8 percent of the subjects were employed. $73.7 \%$ of the participants were having a university education, $88.8 \%$ are having Saudi nationality. Majority $(45.9 \%)$ were from eastern region. Out of these 841 participants 43 were not considered as they were not having children. So, final sample size considered for the study was 798 (95.9\%). Conclusion: In the current study, caregivers have favourable partial understanding deciduous teeth and their worth. Through kids' oral programs with active parental engagement, there is a need to nurture and reinforce good attitudes, as well as significantly enhance their dental awareness.
\end{abstract}

Keywords: Primary Teeth, Oral Prevention, Dental Care, Importance.

\title{
DISCOVERY
}




\section{INTRODUCTION}

Oral health is an essential component of children's health and well-being as dental diseases have an impact on children's everyday activities. Additionally, the quality of their life is reduce due to the psychosocial effect of oral diseases (Azimi et al., 2018). As a result of early childhood caries (ECC), children may also suffer from local infections, oral pain that expresses as complication eating and sleeping, growth inhibition, mental disorders, and a higher risk of caries in permanent dentition (Al-Zahrani et al., 2014). Unfortunately, ECC is an abbreviation for early childhood caries is globally problem due to lack of national program of oral health assessment and primary oral health care (Suma Sogi et al., 2016). This carious process starts after deciduous teeth eruption by $S$. mutans, the main bacterial component involved in dental caries (Dutta et al., 2018). The 1999 to 2004 survey data showed that around 23 per cent of children between 2 and 11 years of age suffer from non-treated caries (Horowitz et al., 2015).

A study found that Bengaluru city parents had just a rudimentary understanding of primary teeth, and that there is a need to improve this information (Moses \& Arunachalam, 2018). The parents' general knowledge of trauma emergency management was unsatisfactory. Although the majority of people were in favour of seeking expert advice for emergency trauma management, the most of them were uninformed of the actions that they needed to take in order to reduce complications and enhance prognosis (Rahul et al., 2016). In 2012, 620 parents of preschool-aged children ages one to four years old participated in a study to measure their knowledge, attitudes, and beliefs about oral health and dental care for their children. The findings demonstrated that barriers to early preventive dental care for preschool children were produced by a lack of understanding and awareness of primary teeth and their value, parental dental phobia, and dental treatment myths (Manar et al., 2018).

Very few researches conducted in particular areas of Saudi Arabia in recent years. Studies have shown variable results regarding the knowledge and attitude of mothers about their kid's dental care. There are a few numbers of sample sizes regarding all regions of Saudi Arabia. This study is planned to assess mothers' knowledge and awareness about their children's dental care also the importance of primary teeth and dental prevention measures.

\section{MATERIALS AND METHODS}

A cross-sectional study was carried out from May 2021 to November 2021. To assess; the parent's knowledge, attitude and practice on their respective children oral health.

All children and their mothers at any age, attending primary health care and hospitals dental clinics and was invited to participate in the study. A convenience sample size of 841 women, aged 20-50 years, with a confidence level of $95 \%$, and a 5\% margin of error was selected Inclusion criteria will be mothers getting their children at any age (males/females) treated for dental caries or had a past dental history and who are willing to participate in Saudi Arabia was included in the study. Mothers, who were not the primary care takers of their children or outside Saudi Arabia, were excluded from these studies.

The survey instrument was a self-administered anonymous questionnaire in both English and Arabic, containing questions regarding knowledge and awareness of children's primary teeth importance and dental care among mothers. On the computer, data was entered using the Office Excel program (2016) for windows. Then data was exported to the IBM SPSS Statistics for Windows, Version 20.0, of the Statistical Package of Social Science Software (SPSS) IBM Corporation, Armonk, New York to do a statistical analysis of the data.

\section{RESULTS AND DISCUSSION}

\section{First section: Study Subjects Personal Information}

Table 1 shows demographic characteristics of the study population. In total there were 841 participants who responded for the questionnaire. The mean age of the study participants was $34.29 \pm 9.43$ years. 40.8 percent of the subjects were employed. Figure 1 shows $73.7 \%$ of the participants were having a university education, $88.8 \%$ are having Saudi nationality. Majority (45.9\%) were from eastern region. Out of these 841 participants 43 were not considered as they were not having children. So final sample size considered for the study was 798 (95.9\%) (Figure 2).

Table 1 Demographic characteristics of study population

\begin{tabular}{llll}
\hline Parameters & $\mathrm{N}$ & Mean & Std. Deviation \\
\hline \multirow{2}{*}{ Age } & \multirow{2}{*}{841} & 34.2961 & 9.43255 \\
\cline { 3 - 4 } & & Frequency & Percentage \\
\hline \multirow{2}{*}{ Occupation } & Employee & 343 & 40.8 \\
\cline { 2 - 4 } & Unemployed & 498 & 59.2 \\
\hline
\end{tabular}




\begin{tabular}{llll}
\hline \multirow{4}{*}{ Education } & Primary & 13 & 1.5 \\
\cline { 2 - 4 } & Intermediate & 33 & 3.9 \\
\cline { 2 - 4 } & Secondary & 165 & 19.6 \\
\cline { 2 - 4 } & University & 620 & 73.7 \\
\cline { 2 - 4 } Nationality & Uneducated & 10 & 1.2 \\
\hline \multirow{4}{*}{\begin{tabular}{llll} 
Region \\
\cline { 2 - 4 }
\end{tabular}} & Saudi & 747 & 88.8 \\
\cline { 2 - 4 } & Non-Saudi & 94 & 11.2 \\
\cline { 2 - 4 } & Southern & 60 & 31.9 \\
\cline { 2 - 4 } & Northern & 35 & 7.1 \\
\hline \multirow{2}{*}{$\begin{array}{l}\text { Do you have } \\
\text { children }\end{array}$} & Eastern & 386 & 45.9 \\
\hline \multirow{2}{*}{$\begin{array}{l}\text { How many } \\
\text { children you } \\
\text { have }\end{array}$} & Central & 92 & 10.9 \\
\cline { 2 - 4 } & Yes & 798 & 94.9 \\
\hline
\end{tabular}

\section{Second section: statements to evaluate mothers' knowledge about Oral hygiene of children less than 5 years}

Table 2 shows mothers' knowledge on various questions related to dental care of the children. $95.5 \%$ of the mothers have agreed that primary teeth need tooth brushing out of which 29.9\% have started brushing their Childs teeth between 10-12 months followed by 2 years (19.8\%). Majority (73.9\%) were using small brush with $48.5 \%$ brushing once daily followed by $45.1 \%$ brushing twice daily. $55.6 \%$ of mothers were using fluoride products $22.3 \%$ were using dental floss (majority once daily $(74.7 \%)$

Table 2 Mothers responses about various questions related to dental care of children.

\begin{tabular}{|c|c|c|c|}
\hline Questions & Response & Frequency & Percentage \\
\hline \multirow{2}{*}{$\begin{array}{l}\text { Do you agree about } \\
\text { brushing primary teeth? }\end{array}$} & Agree & 762 & 95.5 \\
\hline & Disagree & 36 & 4.5 \\
\hline \multirow{8}{*}{$\begin{array}{l}\text { If agree, mention the time } \\
\text { you started brushing your } \\
\text { baby's teeth? }\end{array}$} & 4-5months & 85 & 10.7 \\
\hline & 6-7months & 120 & 15.0 \\
\hline & 8-9months & 99 & 12.4 \\
\hline & 10-12months & 239 & 29.9 \\
\hline & 2years old & 158 & 19.8 \\
\hline & 3 years old & 57 & 7.1 \\
\hline & 4years old & 22 & 2.8 \\
\hline & 5years old & 18 & 2.3 \\
\hline \multirow{4}{*}{$\begin{array}{l}\text { What kind of tools do you } \\
\text { use to brush primary teeth? }\end{array}$} & $\begin{array}{l}\text { Clean, damp } \\
\text { washcloth }\end{array}$ & 89 & 11.2 \\
\hline & Gauze pad & 88 & 11.0 \\
\hline & Small brush & 590 & 73.9 \\
\hline & Other & 31 & 3.9 \\
\hline \multirow{3}{*}{$\begin{array}{l}\text { How many times do you } \\
\text { brush your baby's teeth? }\end{array}$} & Once & 387 & 48.5 \\
\hline & Twice & 360 & 45.1 \\
\hline & More & 51 & 6.4 \\
\hline \multirow{2}{*}{$\begin{array}{l}\text { Do you help your child with } \\
\text { tooth brushing? }\end{array}$} & Yes & 724 & 90.7 \\
\hline & No & 74 & 9.3 \\
\hline \multirow{2}{*}{$\begin{array}{l}\text { Do you use fluoride } \\
\text { products to clean your } \\
\text { baby's teeth? }\end{array}$} & Yes & 444 & 55.6 \\
\hline & No & 354 & 44.4 \\
\hline \multirow{2}{*}{$\begin{array}{l}\text { Do you use dental floss for } \\
\text { your child teeth? }\end{array}$} & Yes & 178 & 22.3 \\
\hline & No & 620 & 77.7 \\
\hline
\end{tabular}




\begin{tabular}{llll}
\hline \multirow{3}{*}{ If yes how many times } & Once & 133 & 74.7 \\
\cline { 2 - 4 } & Twice & 39 & 21.9 \\
\cline { 2 - 4 } & Thrice & 6 & 3.4 \\
\hline
\end{tabular}

\section{Third section: Dental visits}

Table 3 shows table on Childs $84.3 \%$ of mothers are of the view that it is important to follow up with Pedodontist. When the question was asked about the last visit to Pedodontist the percentage varies 3.3 to 18.7 and $49.2 \%$ have told when needed as the reason to visit Pedodontist with dental problem or pain as the cause (46.1\%). Nearly 50\% of the mothers told that their child had bad dental experience. Also, nearly $50 \%$ of mothers are not aware of preventive procedures or caries preventive agents.

Table 3 Mothers responses about various questions related to dental visits.

\begin{tabular}{|c|c|c|c|}
\hline Questions & Response & Frequency & Percentage \\
\hline \multirow{2}{*}{$\begin{array}{l}\text { Is it important to follow up with } \\
\text { pedodontics? }\end{array}$} & Yes & 673 & 84.3 \\
\hline & $\mathrm{No}$ & 125 & 15.7 \\
\hline \multirow{9}{*}{$\begin{array}{l}\text { When was the first time you visited } \\
\text { Pedodontist with your baby? }\end{array}$} & 4-5months & 46 & 5.8 \\
\hline & 6-7months & 38 & 4.8 \\
\hline & 8-9months & 26 & 3.3 \\
\hline & 12months & 149 & 18.7 \\
\hline & 2years old & 148 & 18.5 \\
\hline & 3 years old & 90 & 11.3 \\
\hline & 4years old & 74 & 9.3 \\
\hline & 5years old & 81 & 10.2 \\
\hline & $>$ 5years old & 146 & 18.3 \\
\hline \multirow{4}{*}{$\begin{array}{l}\text { How frequent do you visit } \\
\text { Pedodontist? }\end{array}$} & Once a year & 180 & 22.6 \\
\hline & twice a year & 111 & 13.9 \\
\hline & When needed & 393 & 49.2 \\
\hline & $\begin{array}{l}\text { did not visit Below } 5 \\
\text { years }\end{array}$ & 114 & 14.3 \\
\hline \multirow{3}{*}{$\begin{array}{l}\text { What was the reason for visiting } \\
\text { Pedodontist }\end{array}$} & Routine checkup & 354 & 44.4 \\
\hline & Dental problem/pain & 368 & 46.1 \\
\hline & No response & 76 & 9.5 \\
\hline \multirow{2}{*}{$\begin{array}{l}\text { Have you or your child ever had a } \\
\text { bad dental experience? }\end{array}$} & Yes & 392 & 49.1 \\
\hline & No & 406 & 50.9 \\
\hline \multirow{5}{*}{$\begin{array}{l}\text { Do you know anything about? Please } \\
\text { select the options you know about, if } \\
\text { you don't know please chose "no" }\end{array}$} & No & 396 & 49.6 \\
\hline & space maintainer & 145 & 18.2 \\
\hline & Prophy & 125 & 15.7 \\
\hline & Fissure sealant & 20 & 2.5 \\
\hline & $\begin{array}{l}\text { preventive resin } \\
\text { restorations }\end{array}$ & 112 & 14.0 \\
\hline
\end{tabular}

\section{Forth section: Development of primary teeth and the effect of bad habits}

Table 4 shows questions related to eruption of primary teeth and adverse habits affecting development. 56\% of respondents have told that they know the age of eruption of primary teeth with $5.36 \pm 2.35$ as mean age of eruption. $34.6 \%$ of mothers told the child uses pacifier. $58.8 \%$ of response was received from mothers for not having any adverse habit by the child. $57.6 \%$ of mothers have told that they know the effect of bad habits on primary teeth.

Table 4 Mothers responses about various questions related to eruption of primary teeth and adverse habits affecting development

\begin{tabular}{llll}
\hline Questions & Response & Frequency & Percentage \\
\hline Do you know the age of primary teeth & Yes & 447 & 56.0 \\
\hline
\end{tabular}




\begin{tabular}{|c|c|c|c|}
\hline eruption? & No & 351 & 44.0 \\
\hline $\begin{array}{l}\text { What is the age of primary teeth } \\
\text { eruption? }\end{array}$ & Mean & 5.36 & 2.35 \\
\hline \multirow{2}{*}{ Does your child use a pacifier? } & Yes & 276 & 34.6 \\
\hline & No & 522 & 65.4 \\
\hline \multirow{5}{*}{$\begin{array}{l}\text { Does your child have any of these } \\
\text { habits? }\end{array}$} & No & 469 & 58.8 \\
\hline & $\begin{array}{l}\text { Thumb } \\
\text { sucking }\end{array}$ & 116 & 14.5 \\
\hline & $\begin{array}{l}\text { Mouth } \\
\text { Breathing }\end{array}$ & 86 & 10.8 \\
\hline & Other & 33 & 4.1 \\
\hline & Grind teeth & 94 & 11.8 \\
\hline \multirow{2}{*}{$\begin{array}{l}\text { Do you know the effect of bad habits } \\
\text { in primary teeth development? }\end{array}$} & Yes & 460 & 57.6 \\
\hline & No & 338 & 42.4 \\
\hline
\end{tabular}

\section{Fifth section: Diet}

Table 5 shows questions related to diet of child. $48.2 \%$ of children were fed on bottle $75.2 \%$ of mother's responded that their child was not allowed to carry a bottle or cup during the day containing something other than plain water. $53.5 \%$ of mothers said that their child eats 3 meals a day and $49.6 \%$ of mother told their child have two snacks a day.

Table 5 Mothers responses about various questions related of child

\begin{tabular}{llll}
\hline Questions & Response & Frequency & Percentage \\
\hline \multirow{2}{*}{ Do you put your child in bed with a bottle? } & Yes & 385 & 48.2 \\
\cline { 2 - 4 } & No & 413 & 51.8 \\
\hline Is your child allowed to carry a bottle or cup & Yes & 198 & 24.8 \\
\cline { 2 - 4 } $\begin{array}{l}\text { during the day containing something other } \\
\text { than plain water? }\end{array}$ & No & 600 & 75.2 \\
\hline \multirow{3}{*}{$\begin{array}{l}\text { How many meals per day does your child } \\
\text { eat? }\end{array}$} & 2 meals & 121 & 15.2 \\
\cline { 2 - 4 } & $<2$ meals & 46 & 5.8 \\
\cline { 2 - 4 } & 3 Meals & 427 & 53.5 \\
\cline { 2 - 4 } & $>3$ meals & 204 & 25.6 \\
\hline \multirow{3}{*}{ How many snacks does your child eat? } & Once & 151 & 18.9 \\
\cline { 2 - 4 } & Two & 396 & 49.6 \\
\cline { 2 - 4 } & Three & 139 & 17.4 \\
\cline { 2 - 4 } & $>$ three & 75 & 9.4 \\
\cline { 2 - 4 } & No snacks & 37 & 4.6 \\
\hline
\end{tabular}

The following responses to questions were found statistically significant when compared according to employment status of mothers (table 6). The time when they started brushing their teeth, use of dental floss number of times they use dental floss, follow up with Pedodontist, reason for visiting Pedodontist, knowledge about preventive procedures and fluorides, use of pacifiers and child allowing to carry bottle or cup during the day containing something other than plain water. When compared according to educational status the knowledge level varied significantly and most of the questions were found to be statistically significant as shown in table 7.

Table 6 Comparison of mother's knowledge to various questions according to occupation

\begin{tabular}{llll}
\hline Questions & $\chi^{2}$ & $\mathrm{p}$ value & Significance \\
\hline Do you agree about brushing primary teeth? & 2.123 & 0.166 & NS \\
\hline $\begin{array}{l}\text { If agree, mention the time you started brushing your } \\
\text { baby's teeth? }\end{array}$ & 15.30 & 0.032 & $\mathrm{~S}$ \\
\hline
\end{tabular}




\begin{tabular}{|c|c|c|c|}
\hline What kind of tools do you use to brush primary teeth? & 6.86 & 0.076 & NS \\
\hline How many times do you brush your baby's teeth? & 5.48 & 0.065 & NS \\
\hline Do you help your child with tooth brushing? & 0.411 & 0.537 & NS \\
\hline Do you use fluoride products to clean your baby's teeth? & 2.31 & 0.129 & NS \\
\hline Do you use dental floss for your child teeth? & 10.59 & 0.001 & S \\
\hline If yes how many times & 11.39 & 0.010 & S \\
\hline Is it important to follow up with pedodontics? & 5.073 & 0.029 & S \\
\hline $\begin{array}{l}\text { When was the first time you visited Pedodontist with } \\
\text { your baby? }\end{array}$ & 18.01 & 0.021 & S \\
\hline How frequent do you visit Pedodontist? & 24.66 & $<0.001$ & HS \\
\hline What was the reason for visiting Pedodontist & 7.33 & 0.007 & $S$ \\
\hline $\begin{array}{l}\text { Have you or your child ever had a bad dental } \\
\text { experience? }\end{array}$ & 3.04 & 0.085 & NS \\
\hline $\begin{array}{l}\text { Do you know anything about? Please select the options } \\
\text { you know about, if you don't know please chose "no" }\end{array}$ & 14.87 & 0.005 & S \\
\hline Do you know the age of primary teeth eruption? & 0.470 & 0.515 & NS \\
\hline What is the age of primary teeth eruption? & 8.46 & 0.67 & NS \\
\hline Does your child use a pacifier? & 5.53 & 0.019 & S \\
\hline Does your child have any of these habits? & 6.87 & 0.143 & NS \\
\hline $\begin{array}{l}\text { Do you know the effect of bad habits in primary teeth } \\
\text { development? }\end{array}$ & 1.33 & 0.275 & NS \\
\hline Do you put your child in bed with a bottle? & 3.92 & 0.052 & NS \\
\hline $\begin{array}{l}\text { Is your child allowed to carry a bottle or cup during the } \\
\text { day containing something other than plain water? }\end{array}$ & 6.76 & 0.010 & S \\
\hline How many meals per day does your child eat? & 6.40 & 0.09 & NS \\
\hline How many snacks does your child eat? & 1.79 & 0.773 & NS \\
\hline
\end{tabular}

Table 7 Comparison of mother's knowledge to various questions according to educational level

\begin{tabular}{|c|c|c|c|}
\hline Questions & $\chi^{2}$ & $\mathrm{p}$ value & Significance \\
\hline Do you agree about brushing primary teeth? & 23.04 & $<0.001$ & HS \\
\hline $\begin{array}{l}\text { If agree, mention the time you started brushing your baby's } \\
\text { teeth? }\end{array}$ & 76.91 & $<0.001$ & HS \\
\hline What kind of tools do you use to brush primary teeth? & 54.73 & $<0.001$ & HS \\
\hline How many times do you brush your baby's teeth? & 11.94 & 0.154 & NS \\
\hline Do you help your child with tooth brushing? & 41.83 & $<0.001$ & HS \\
\hline Do you use fluoride products to clean your baby's teeth? & 5.61 & 0.23 & NS \\
\hline Do you use dental floss for your child teeth? & 30.25 & $<0.001$ & HS \\
\hline If yes how many times & 52.31 & $<0.001$ & HS \\
\hline Is it important to follow up with pedodontics? & 10.81 & 0.029 & S \\
\hline $\begin{array}{l}\text { When was the first time you visited Pedodontist with your } \\
\text { baby? }\end{array}$ & 92.13 & $<0.001$ & HS \\
\hline How frequent do you visit Pedodontist? & 17.62 & 0.128 & NS \\
\hline What was the reason for visiting Pedodontist & 5.82 & 0.212 & NS \\
\hline Have you or your child ever had a bad dental experience? & 14.37 & 0.06 & S \\
\hline $\begin{array}{l}\text { Do you know anything about? Please select the options you } \\
\text { know about, if you don't know please chose "no" }\end{array}$ & 55.58 & $<0.001$ & HS \\
\hline Do you know the age of primary teeth eruption? & 32.12 & $<0.001$ & HS \\
\hline
\end{tabular}




\begin{tabular}{|c|c|c|c|}
\hline What is the age of primary teeth eruption? & 44.47 & 0.088 & NS \\
\hline Does your child use a pacifier? & 9.03 & 0.060 & NS \\
\hline Does your child have any of these habits? & 30.57 & 0.015 & $\mathrm{~S}$ \\
\hline $\begin{array}{l}\text { Do you know the effect of bad habits in primary teeth } \\
\text { development? }\end{array}$ & 18.15 & 0.001 & $\mathrm{~S}$ \\
\hline Do you put your child in bed with a bottle? & 6.35 & 0.174 & NS \\
\hline $\begin{array}{l}\text { Is your child allowed to carry a bottle or cup during the day } \\
\text { containing something other than plain water? }\end{array}$ & 10.57 & 0.032 & S \\
\hline How many meals per day does your child eat? & 19.36 & 0.080 & NS \\
\hline How many snacks does your child eat? & 43.42 & $<0.001$ & HS \\
\hline
\end{tabular}

Table 8 \& figure 1 and 2 shows comparison according to region status the knowledge level varied significantly almost all the questions were found to be statistically significant $(\mathrm{p}<0.05)$ except tools used to brush the teeth, use of fluoride products to clean the teeth, having a childs bad dental experience and child allowing to carry bottle or cup during the day containing something other than plain water.

Table 8 Comparison of mother's knowledge to various questions according to region

\begin{tabular}{|c|c|c|c|}
\hline Questions & $\chi^{2}$ & $\mathrm{p}$ value & Significance \\
\hline Do you agree about brushing primary teeth? & 34.41 & $<0.001$ & HS \\
\hline $\begin{array}{l}\text { If agree, mention the time you started brushing your } \\
\text { baby's teeth? }\end{array}$ & 61.61 & $<0.001$ & HS \\
\hline What kind of tools do you use to brush primary teeth? & 17.18 & 0.143 & NS \\
\hline How many times do you brush your baby's teeth? & 21.92 & 0.005 & S \\
\hline Do you help your child with tooth brushing? & 22.70 & $<0.001$ & HS \\
\hline Do you use fluoride products to clean your baby's teeth? & 1.43 & 0.838 & NS \\
\hline Do you use dental floss for your child teeth? & 13.59 & 0.009 & S \\
\hline If yes how many times & 86.60 & $<0.001$ & HS \\
\hline Is it important to follow up with pedodontics? & 38.58 & $<0.001$ & HS \\
\hline $\begin{array}{l}\text { When was the first time you visited Pedodontist with your } \\
\text { baby? }\end{array}$ & 93.87 & $<0.001$ & HS \\
\hline How frequent do you visit Pedodontist? & 28.94 & 004 & $S$ \\
\hline What was the reason for visiting Pedodontist & 42.86 & $<0.001$ & HS \\
\hline Have you or your child ever had a bad dental experience? & 2.344 & 0.673 & NS \\
\hline $\begin{array}{l}\text { Do you know anything about? Please select the options } \\
\text { you know about, if you don't know please chose "no" }\end{array}$ & 36.73 & 0.002 & S \\
\hline Do you know the age of primary teeth eruption? & 14.54 & 0.006 & $S$ \\
\hline What is the age of primary teeth eruption? & 81.04 & 001 & S \\
\hline Does your child use a pacifier? & 13.32 & 0.010 & S \\
\hline Does your child have any of these habits? & 45.81 & $<0.001$ & HS \\
\hline $\begin{array}{l}\text { Do you know the effect of bad habits in primary teeth } \\
\text { development? }\end{array}$ & 15.64 & 0.004 & S \\
\hline Do you put your child in bed with a bottle? & 14.07 & 0.007 & $\mathrm{~S}$ \\
\hline $\begin{array}{l}\text { Is your child allowed to carry a bottle or cup during the } \\
\text { day containing something other than plain water? }\end{array}$ & 4.98 & 0.289 & NS \\
\hline How many meals per day does your child eat? & 35.79 & $<0.001$ & HS \\
\hline How many snacks does your child eat? & 31.39 & 0.012 & $\mathrm{~S}$ \\
\hline
\end{tabular}




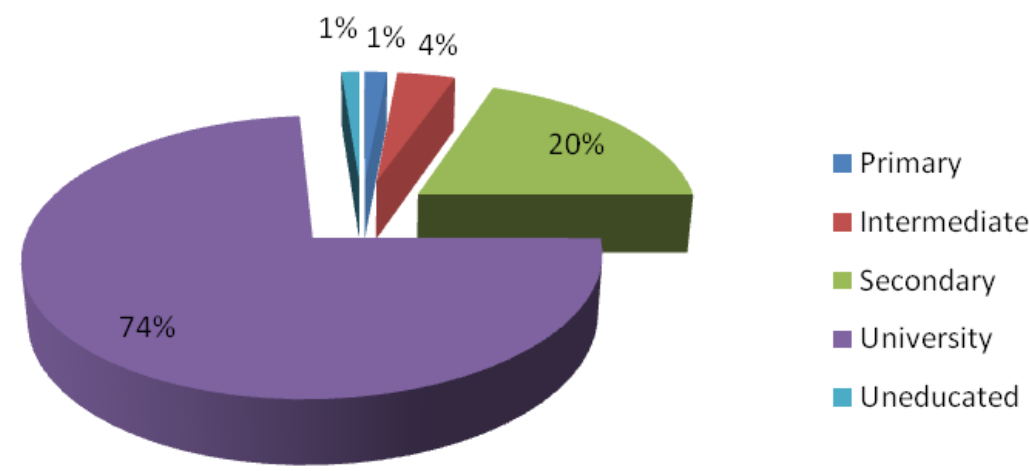

Figure 1 Educational status of study participants

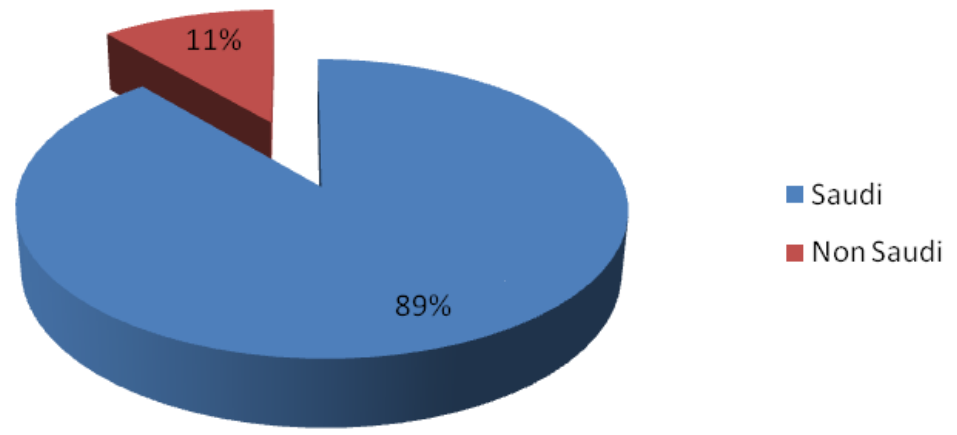

Figure 2 Nationality of study participants

\section{DISCUSSION}

Children's oral health is related to their mothers'/guardians' oral health knowledge, even though oral health related patterns (including those related to oral hygiene and nutrition) are established during infancy and sustained throughout early childhood (Wendt et al., 1996; Almotawah et al., 2021). Parents, especially mothers, function as in order to serve as positive examples for their kids. This research adds significant new evidence to the knowledge base about mothers' attitudes toward oral primary dentition and preventive dental measures. The questionnaires specifically target mothers' knowledge of Oral hygiene of children under 5 years, dental visits, eruption of primary teeth and adverse habits affecting development and questions related of child diet.

\section{Oral hygiene practices}

Knowledge regarding the oral hygiene practice which includes brushing, when did they start brushing child teeth, tools used to brush teeth, number of times they brush the teeth, use of fluoride products for brushing, use of dental floss were asked in this section. 95.5\% of mother agreed about brushing primary teeth. Similar result was found in an Australian study (Gussy et al., 2008). According to a study conducted by Gussy et al., (2008) 95 percent of parents in rural Australia believed that they should begin brushing when the first tooth erupts. The majority of our research study participants (29.9\%) reported that they started brushing at 10-12 months of age. In the present study $73.9 \%$ uses a small toothbrush to clean teeth similar to $85 \%$ of an Indian study by Gurunathan et al., (2018) where they reported 85\% of mothers agree to brush their child teeth. Hence, the mothers do understand the advantage for brushing. Pullishery et al., (2013) reported majority of mothers agreed brushing of children needed to be supervised till 5 years in their study; similar trend was seen in our study (90.7). 55.6\% of mothers in the current study use fluoride products to clean their Childs teeth. Slightly lower percentage was reported by Sehrawat et al., (2016) where 43\% could identify the importance of adding fluoride to toothpaste.

In the present study, we included mother's education, occupation and region as factors for comparing their knowledge. Previous studies showed these factors (Shaghaghian et al., 2017; 2019). Our research found that a substantial education level can have a negative impact on parents' understanding and awareness of their children's oral health. There was a significant relationship between parental education levels and geographic area in the current study. As a result, parental education may significantly impact their children's oral health. Our findings are consistent with those of other studies in the literature (Shaghaghian et al., 2017). 


\section{Second section}

\section{Dental visits}

In the present study, $19.7 \%$ of mothers first visited a Pedodontist at the age of 12 months with $46.1 \%$ reporting pain as the reason for dental visit. Nearly $50 \%$ of respondents told they visit Pedodontist when needed only and on routinely. The American Academy of Paediatric Dentistry recommends that all infants have a dental home by 12 months (Chen et al., 2021). It also asserts regular visits to the dentist after the initial consultation, but due to the unavailability of primary care in developing nations, it was discovered that parents do not follow these suggestions. According to research, parents in underdeveloped nations do not follow these instructions, and one explanation for this might be a lack of priority placed on the primary school (Lahti et al., 1999) socioeconomic, (Paunio, 1994) and educational status, (Källestål \& Wall, 2002) besides cultural beliefs.

\section{Third section}

\section{Eruption of primary teeth and adverse habits affecting development}

Knowledge on eruption sequence of deciduous and permanent teeth helps to prevent future malocclusion in the child. In this study $56 \%$ of mothers told they know the age of eruption of primary teeth. Preventive measures can help in reducing the incidence of malocclusion in children. Especially the adverse habits such as mouth breathing, tongue thirsting, thumb sucking etc. From the start, these behaviours must be detected and corrected (Freeman, 1977).

Parents want their babies to be happy. Giving a pacifier to a wailing infant is one approach to calm him or her down. Pacifiers can be a terrific way to keep a new born happy, but they can also be harmful to your child's health. Overuse of a pacifier might lead to poor tooth growth in a new born. In the current study $34.6 \%$ have told they use pacifiers. Pacifiers offer advantages, yet they can be harmful to a child's dental health. Sucking on a pacifier or a child's thumb can have an influence on the right growth patterns of the child's mouth and new born teeth. A pacifier can also interfere with the healthy development of the roof of the mouth. These problems are especially frequent in toddlers who use a pacifier (Savage et al., 2007). The availability and accessibility of nutritious food are characteristics related with good eating patterns at home (Cullen et al., 2003). Parents may encourage children to consume fruits and vegetables by offering them at meals and eating them themselves. Parents, on the other hand, might encourage the habitual use of inexpensive, highly delicious, energy-dense meals, such as sweetened beverages and snacks, which can contribute to caries, overeating, and weight gain. To counteract these trends, parents want assistance on food selection and the cost-to-nutrient ratio (Savage et al., 2007). Planned meal and snacking behaviours, with one to three daily snacks, are preferred over unlimited access to $100 \%$ juice, other sugared beverages and snacks over the course of the day. Such behaviours favour the intake of nutrientpoor foods and increase the risk of obesity and dental caries (Marshall et al., 2005).

\section{CONCLUSION}

Care givers in the present study have positive partial knowledge on primary teeth and importance. There is a need to create and maintain good attitudes among children, as well as significantly increase their dental knowledge, through child oral health-oriented programs with active parental participation. Such awareness programmes should be developed for parents imparting knowledge about primary teeth, their functions and preventive primary care of these teeth. It should be a multidisciplinary approach where medical professionals, gynecologists, pediatricians should join hands.

\section{Informed Consent}

Informed consent was obtained from all participants included in the study.

\section{Ethical approval}

Ethical approval was obtained from Research Ethics Committee at Ibn Sina National College with IRB number (IRRB-01-15102021).

\section{Funding}

The study did not receive any external funding

\section{Conflict of interests}

The authors declare that there are no conflicts of interests.

Data and materials availability

All data associated with this study are present in the paper. 


\section{REFERENCES AND NOTES}

1. Almotawah F, Al Obaida H, Abuhaimed N, Al Obaida R, Al Otaibi S, Altassan Y. The awareness of parents on the relation of the quality of diet and its effect on the incidence of caries in primary school children in Riyadh. Medical Science 2021;25(112):1338-1345

2. Al-Zahrani AM, Al-Mushayt AS, Otaibi MF, Wyne AH. Knowledge and attitude of Saudi mothers towards their preschool children's oral health. Pak J Med Sci 2014; 30(4); 720-724.

3. Azimi S, Taheri JB, Tennant M, Kruger E, Molaei H, Ghorbani Z. Relationship between mothers' knowledge and attitude towards the importance of oral health and dental status of their young children. Oral Health Prev Dent 2018; 16(3):265-70.

4. Chen KJ, Duangthip D, Gao SS, Huang F, Anthonappa RP, Oliveira BH. Oral health policies to tackle the burden of early childhood caries: a review of 14 countries/regions. Front Oral Heal 2021; 2:30.

5. Cullen KW, Baranowski T, Owens E, Marsh T, Rittenberry L, de Moor C. Availability, accessibility, and preferences for fruit, $100 \%$ fruit juice, and vegetables influence children's dietary behavior. Heal Educ Behav Off Publ Soc Public Heal Educ 2003; 30(5):615-26.

6. Dutta B, Singh Dhull K, Samir P, Devraj IM. Knowledge, Attitude, and Practice of Mothers towards Infant Oral Healthcare. Int J Clin Pediatr Dent 2018; 11(5):435-9.

7. Freeman JD. Preventive and interceptive orthodontics: a critical review and the results of a clinical study. J Prev Dent 1977; 4(5):7-14, 20-23.

8. Gurunathan D, Moses J, Arunachalam SK. Knowledge, Attitude, and Practice of Mothers regarding Oral Hygiene of Primary School children in Chennai, Tamil Nadu, India. Int J Clin Pediatr Dent 2018; 11(4):338-43.

9. Gussy MG, Waters EB, Riggs EM, Lo SK, Kilpatrick NM. Parental knowledge, beliefs and behaviours for oral health of toddlers residing in rural Victoria. Aust Dent J 2008; 53(1):52-60.

10. Horowitz AM, Kleinman D V., Child W, Maybury C. Perspectives of Maryland adults regarding caries prevention. Am J Public Health 2015; 105(5):58-64.

11. Källestål C, Wall S. Socio-economic effect on caries. Incidence data among Swedish 12-14-year-olds. Community Dent Oral Epidemiol 2002; 30(2):108-14.

12. Lahti SM, Hausen HW, Vaskilampi T. The perceptions of users about barriers to the use of free systematic oral care among Finnish pre-school children - A qualitative study. Acta Odontol Scand 1999; 57(3):139-43.
13. Marshall TA, Broffitt B, Eichenberger-Gilmore J, Warren JJ, Cunningham MA, Levy SM. The roles of meal, snack, and daily total food and beverage exposures on caries experience in young children. J Public Health Dent 2005; 65(3):166-73.

14. Moses J, Arunachalam SK. Knowledge, Attitude, and Practice of Mothers regarding Oral Hygiene of Primary School children in Chennai, Tamil Nadu, India. Int J Clin Pediatr Dent 2018; 11(4):338-43.

15. Paunio P. Dental health habits of young families from southwestern Finland. Community Dent Oral Epidemiol 1994; 22(1):36-40.

16. Pullishery F, Shenoy Panchmal G, Shenoy R. Parental Attitudes and Tooth Brushing Habits in Preschool Children in Mangalore, Karnataka: A Cross-sectional Study. Int J Clin Pediatr Dent 2013; 6(3):156-60.

17. Savage JS, Fisher JO, Birch LL. Parental influence on eating behavior: conception to adolescence. J Law Med Ethics 2007; 35(1):22-34.

18. Sehrawat P, Shivlingesh KK, Gupta B, Anand R, Sharma A, Chaudhry M. Oral health knowledge, awareness and associated practices of pre-school children's mothers in Greater Noida, India. Niger Postgrad Med J 2016; 23(3):1527.

19. Shaghaghian S, Savadi N, Amin M, Hamasha AA-H, Rasheed SJ, Aldosari MM, et al. Parents Knowledge and Awareness of their Children's Oral Health in Riyadh, Saudi Arabia. Open Dent J 2019; 13(1):236-41.

20. Shaghaghian S, Savadi N, Amin M. Evaluation of parental awareness regarding their child's oral hygiene. Int J Dent Hyg 2017; 15(4):e149-55.

21. Suma Sogi H, Hugar S, Nalawade T, Sinha A, Hugar S, Mallikarjuna R. Knowledge, attitude, and practices of oral health care in prevention of early childhood caries among parents of children in Belagavi city: A Questionnaire study. J Fam Med Prim Care 2016; 5(2):286.

22. Wendt LK, Hallonsten AL, Koch G, Birkhed D. Analysis of caries-related factors in infants and toddlers living in Sweden. Acta Odontol Scand 1996; 54(2):131-7. 